\title{
PERANCANGAN APLIKASI TELEGRAM UNTUK MONITORING DAN KENDALI KOLAM IKAN OTOMATIS
}

\author{
Putri Elfa Mas`udia, Megasari Wulan Sakti, Saddoni Mei Raharjo, Aad Hariyadi, Ahmad Wahyu Purwandi \\ Jurusan Teknik Elektro, Politeknik Negeri Malang \\ Putri.elfa@politeknik.ac.id
}

(Artikel diterima: Februari 2020, direvisi: April 2020, diterima untuk terbit: Juli 2020)

\begin{abstract}
Abstrak - Ikan lele termasuk salah satu hewan yang banyak dikonsumsi oleh masyarakat Indonesia. Cara perawatan dan perkembang biakan ikan lele relatif lebih mudah, namun kebanyakan pengontrolan terhadap kualitas air kolam yang meliputi suhu, tingkat keasaman, dan tingkat kekeruhan air masih dilakukan secara manual menggunakan alat ukur. Untuk pemberian pakan ikan dan pengurasan kolam juga dilakukan secara manual, hal ini tentu saja kurang efektif dan memungkinkan terjadinya human eror. Beberapa alat telah dikembangkan untuk mengatasi permasalahan diatas namun terbatas pada output yang hanya bisa diakses pada jarak yang dekat. Pada penelitian ini penulis ingin melakukan pengembangan dengan memanfaatkan aplikasi telegram untuk dapat memonitoring kualitas air dan melakukan kontrol dari jarak yang jauh dengan memanfaatkan aplikasi telegram. Sistem ini dibuat menggunakan Arduino sebagai mikrokontroler dan berbagai alat pendukung seperti Sensor Suhu DS18B20, Sensor pH E201C, Sensor Turbidity MJKDZ, Sensor Ultrasonik JSN-SR04. Hasil pembacaan dari sensor telah berhasil ditampilkan pada Bot Telegram dengan rata-rata error sebesar 1,02\% dan mampu memberikan perintah sesuai dengan tombol yang tersedia dengan delay sebesar $14.008 \mathrm{~ms}$. Petani ikan dapat mengetahui keadaan kolam secara real time, mampu melakukan kontrol secara sederhana dan mampu memberikan pakan secara otomatis selama 0.5 detik dengan berat $5 \%$ dari bobot ikan lele
\end{abstract}

Kata kunci: jumlah, kata, kunci, minimal, lima, kata.

\section{Pendahuluan}

Ikan lele termasuk salah satu hewan yang banyak dikonsumsi oleh masyarakat Indonesia. Selain sebagai sumber protein hewani, cara perawatan dan perkembang biakan ikan lele relatif lebih mudah. Beberapa faktor yang harus diperhatikan agar menghasilkan ikan dengan kualitas yang baik adalah kualitas air dan pemberian waktu makan yang tepat. Menurut SNI [9], "Ikan lele (Clarias sp.) bagian 3, kualitas air merupakan hal utama dalam melakukan budidaya ikan lele yang meliputi suhu yaitu $25-30^{\circ} \mathrm{C}$, ph optimal yaitu $6,5-8$, dan kekeruhan kurang dari 400 NTU. Serta pemberian pakan ikan diberikan sekitar 2 - 5\% per hari atau bahkan lebih.

Yang banyak terjadi saat ini adalah para petani ikan lele melakukan pengontrolan terhadap kualitas air yang meliputi suhu, tingkat keasaman, dan tingkat kekeruhan air secara manual menggunakan alat ukur. Untuk pemberian pakan ikan dan pengurasan kolam juga dilakukan secara manual, hal ini tentu saja kurang efektif dan memungkinkan terjadinya human eror.

Beberapa alat telah dikembangkan untuk mengatasi permasalahan diatas, antara lain jurnal yang dibuat oleh Rozeff Pramana tahun 2018 dengan judul "Perancangan Sistem Kontrol dan Monitoring Kualitas Air dan Suhu Air Pada Kolam Budidaya Ikan" tentang perangkat sistem kontrol dan monitoring otomatis kualitas air pada kolam budidaya ikan berbasis Web melalui komputer/laptop [5], jurnal yang dibuat oleh Ghulam Imaduddin, dan Andi Saprizal tahun 2017 dengan judul "Otomatisasi Monitoring dan Pengaturan Keasaman Larutan dan Suhu Air Kolam Ikan pada Pembenihan Ikan Lele" tentang otomatisasi monitoring kadar PH dan suhu dengan output ditampilkan pada layar LCD dan pada monitor dalam bentuk grafik [4], dan jurnal yang dibuat Riskan Oktafiadi tahun 2016 dengan judul "Sistem Pemantau Kekeruhan Air dan Pemberi Makan Otomatis pada Ikan Berbasis Mikrokontroler" tentang pemberian makan tiga kali sehari secara otomatis dan mengukur tingkat kekeruhan air menggunakan sensor yang diolah oleh mikrokontroler sebagai pengendali dengan output ditampilkan pada layar LCD diikuti nyala LED [6].

Hasil output dari beberapa penelitian tersebut masih memiliki keterbatasan, yaitu hanya ditampilkan melalui LCD / Monitor atau website dan belum bisa melakukan aksi (kendali) dari jarak jauh.

Dari permasalahan tersebut, penulis ingin melakukan pengembangan dengan memanfaatkan aplikasi telegram untuk dapat memonitoring kualitas air dan melakukan kontrol dari jarak yang jauh. Telegram adalah sebuah aplikasi layanan pengirim pesan instan multiplatfrom berbasis awan yang bersifat gratis nirbala [3]. Aplikasi ini sangat diminati dan memiliki banyak anggota, menurut Pavel Durov, aplikasi chatting telegram pada tahun 2018 telah memiliki 200 juta pengguna aktif [8]. Hal ini dikarenakan telegram memiliki beberapa keunggulan yaitu telegram membuka Aplication Programming Interface (API) sehingga memungkinkan para pengembang aplikasi untuk menambah tools sesuai dengan kebutuhan, ukuran file yang dapat dikirimkan melalui telegram juga sangat besar, yaitu dapat mengirimkan file hingga $1.5 \mathrm{~Gb}$. Telegram juga menyediakan bots, yakni program berbasis kecerdasan buatan dan machine learning yang dapat melakukan beberapa tugas [7].

Adapun rumusan masalah dalam penelitian ini adalah bagaimana cara merancang aplikasi telegram untuk dapat memonitoring suhu, ph dan tingkat kekeruhan air serta dapat melakukan kendali jarak jauh.

Telegram pada penelitian ini berfungsi sebagai monitoring suhu, tingkat kekeruhan, $\mathrm{PH}$ dan pengendalian alat jarak jauh. Untuk dapat terhubung dengan alat, telegram menyediakan key/API yang bisa didapatkan dengan cara mendaftarkannya melalui layanan BotFather . 


\section{Metode Penelitian}

Perencanaan software merupakan tahapan dari rencana tampilan dan menu dari Bot Telegram sesuai kebutuhan dalam pembuatan sistem. Perencanaan sistem berfungsi untuk menentukan input dan output yang akan muncul pada Bot Telegram.

\section{A. Blok Diagram Sistem}

Perancangan sistem mengenai sistem monitoring dan telekontrol budidaya ikan lele menggunakan telegram dapat dijelaskan pada diagram berikut:

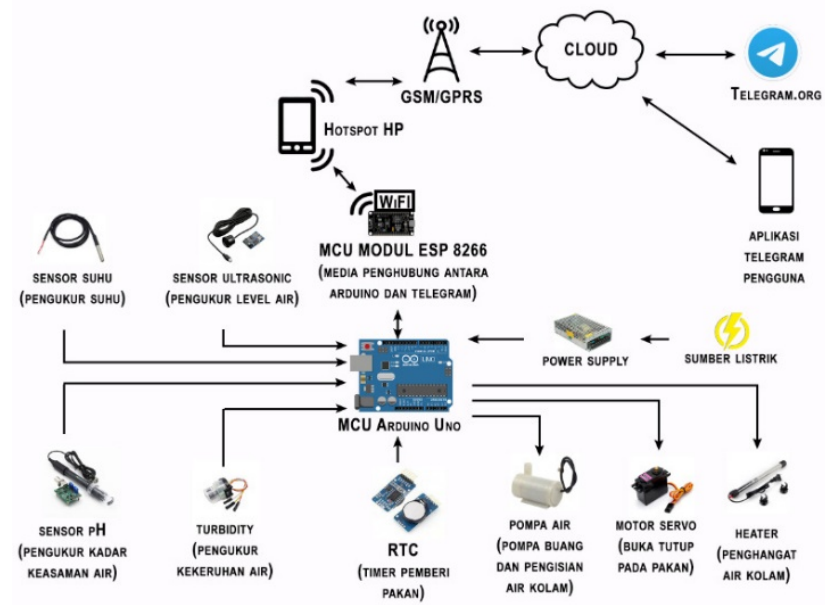

Gambar 1. Blok Diagram Sistem

Terdapat beberapa sensor yang digunakan dalam perancangan, diantaranya sensor suhu untuk mendeteksi suhu air, sensor ultrasonik untuk mendeteksi ketinggian air, sensor turbidity untuk mengukur tingkat kekeruhan air, dan sensor PH untuk mendeteksi tingkat keasaman air. Jika suhu terdeteksi berada dibawah $25^{\circ} \mathrm{C}$ maka arduino akan memberi perintah untuk mengaktifkan heater. Jika kekeruhan air terdeteksi lebih dari 400 dan ph dibawah 6.5 maka arduino akan memberi perintah untuk melakukan pengurasan dengan membuang air dan mengaktifkan pompa untuk mengisi air yang baru.

Perancangan juga dilakukan untuk alat pemberian pakan ikan secara otomatis, sehingga waktu pemberian pakan ikan dapat disetting sesuai kebutuhan, jika waktu sesuai maka arduino akan memberi perintah pada motor servo untuk buka/tutup pakan ikan.

Sedangkan aplikasi telegram digunakan untuk mengontrol dan memonitoring alat yang berada pada kolam dari jarak jauh, berguna sebagai fasilitas jika petani ikan ingin memberi perintah selain dari waktu yang telah ditentukan maupun meminta informasi tentang kondisi kolam. Pengiriman data dari arduino ke Telegram dilakukan dengan cara memanfaatkan Modul ESP8266 yang terhubung ke internet, semakin baik jaringan internet maka semakin cepat pengiriman data tersebut [2].

\section{B. Flowchart Sistem}

Alur keseluruhan sistem ditunjukkan pada flowchart sistem berikut:

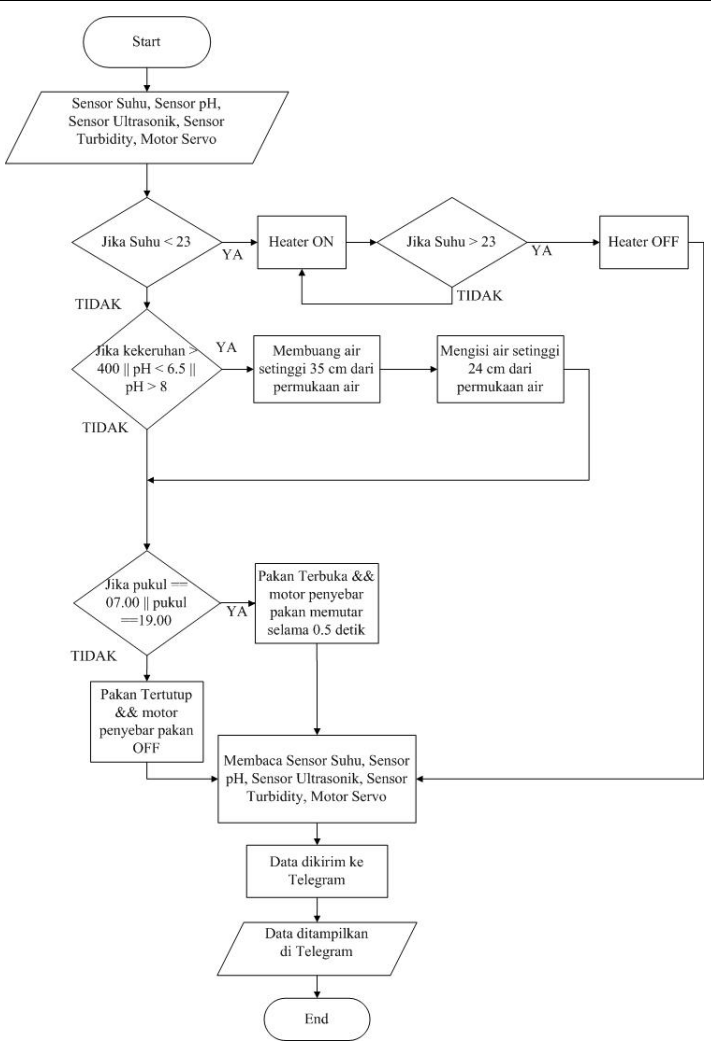

Gambar 2. Flowchart Sistem

Pertama sensor akan membaca data sesuai yang telah diatur sebelumnya. Jika data tidak sesuai, maka mikrokontroler memberikan perintah untuk menghidupkan kontrol secara otomatis. Setiap data yang dibaca hasilnya akan dikirimkan ke telegram sebagai pesan sehingga user dapat memonitoring keadaan kolam. User juga dapat melakukan kontrol secara manual jika kontrol otomatis tidak berfungsi atau ingin menghidupkan sesuai keinginan.

\section{Perancangan Mekanik}

Perencanaan mekanik merupakan tahapan dari proses pembuatan alat sebagai media kontrol dan monitor secara otomatis maupun manual pada kolam ikan lele yang menggunakan bak sebagai media praktik dengan memanfaatkan Telegram sebagai software untuk memberikan perintah. Gambar 3 merupakan perencanaan dari rangkaian mekanik yang akan dibuat.

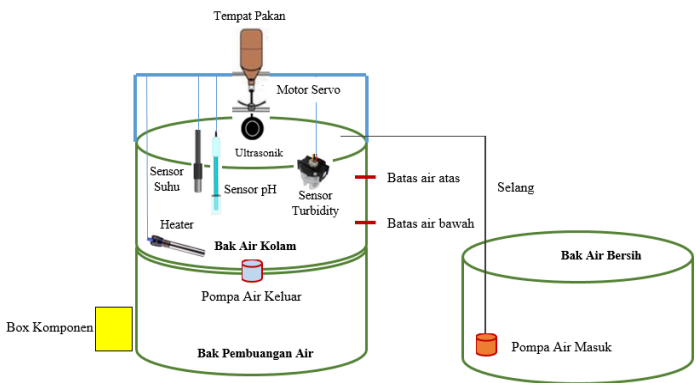

Gambar 3. Rangkaian Mekanik

Power supply digunakan sebagai catu daya alat tersebut sehingga alat dapat aktif dan berfungsi. Arduino merupakan mikrokontoler yang terhubung dengan beberapa perangkat lainnya seperti sensor dan modul ESP8266 yang memungkinkan mengakses mikrokontroler melalui internet. Sensor Turbidity digunakan untuk mengetahui kepekatan air kolam, sensor suhu digunakan untuk mengetahui suhu air kolam, sensor ph digunakan untuk mengetahui tingkat 
keasaman air kolam, sensor ultrasonik berfungsi untuk level maksimum dan minimum air. Pada gambar terlihat adanya dinamo yang digunakan untuk memutar pipa sebagai media penyebar pakan ikan. Motor servo digunakan untuk membuka maupun menutup katup pakan ikan yang nantinya akan dijatuhkan tepat ke area pipa untuk disebar.

Motor pembuangan air terletak pada bagian bawah bak berfungsi untuk menguras air kolam ke bak pembuangan air. Selain itu terdapat pompa air yang diletakkan pada bak air bersih berfungsi untuk mempompa air bersih masuk ke kolam ikan melalui selang air.

\section{Perancangan Aplikasi Telegram}

Perencanaan software merupakan tahapan dari rencana tampilan dan menu dari Bot Telegram sesuai kebutuhan dalam pembuatan sistem. Perencanaan sistem berfungsi untuk menentukan input dan output yang akan muncul pada Bot Telegram. Flowchart Perencanaan software ditunjukkan pada Gambar 4.

Prosedur komunikasi sistem merupakan cara tentang jalannya pengiriman perintah dan data dari sistem ke Telegram maupun sebaliknya. Adapun beberapa hal yang harus diperhatikan untuk membangun komunikasi sistem ke Telegram maka diperlukan beberapa library komunikasi yaitu ESP8266Wifi.h, WiFiClientSecure.h, dan

UniversalTelegramBot.

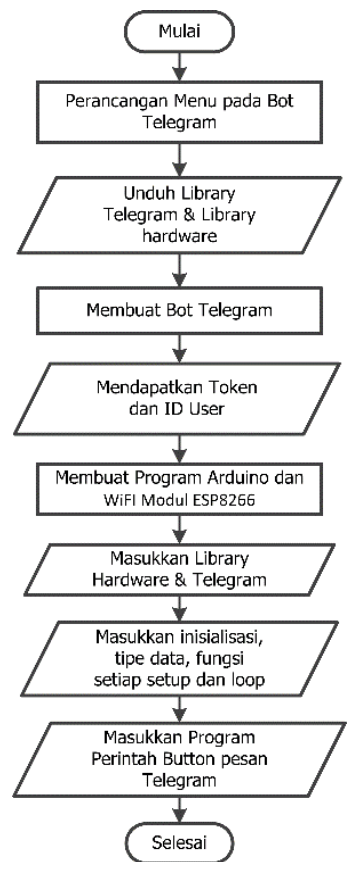

Gambar 4. Flowchart Perencanaan Software

\section{1) Library}

Library yang digunakan untuk menghubungkan antara Bot Telegram dan Modul ESP adalah sebagai berikut:

- ESP8266WiFi.h merupakan perpustakaan kode milik modul ESP8266 berfungsi untuk menghubungkan ke jaringan internet melalui SSID dan password. Adanya library ini sebagai kode untuk menghubungkan aplikasi Arduino IDE dengan Modul ESP sehingga ketika pengguna melakukan upload dapat melalui Modul ESP yang digunakan.

- WiFiClientSecure.h merupakan file library bagian inti dari ESP8266 pada Arduino IDE, contoh penggunaan
- UniversalTelegramBot.h merupakan library yang berfungsi untuk menghosting Bot Telegram di Arduino sehingga dapat berinteraksi dengan API Bot Telegram dengan memanfaatkan token akses yang telah diberikan kepada pengguna.

*include "TelegramBot. $\mathrm{h}$ "

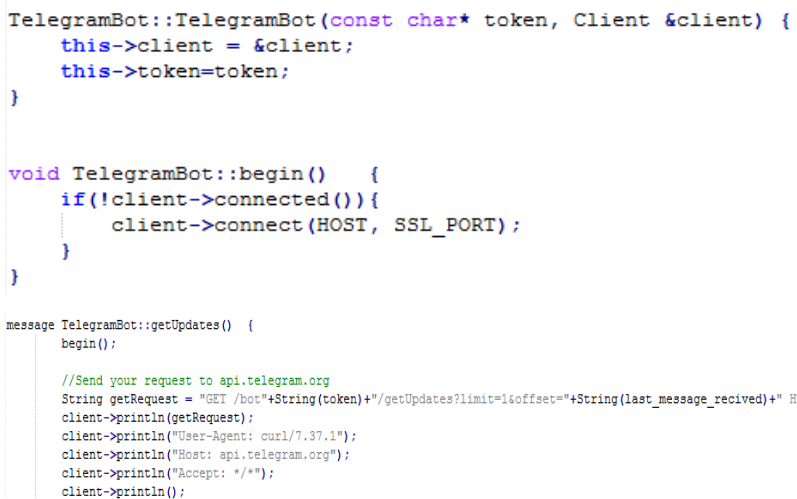

Gambar 5. Program Koneksi ke Telegram

Kode di atas merupakan isi dari library UniversalTelegramBot.h yang berfungsi untuk menghubungkan ke API Telegram dan memberikan pesan ke client Bot Telegram.

\section{2) Bot Telegram}

Bot Telegram digunakan untuk membuat sebuah bot baru pada akun Telegram pengguna. Telegram mempunyai fitur bernama "Bot Father" untuk memulai membuat bot. Langkah awal yang harus dilakukan adalah mengetikkan "Bot Father" pada kolom search. Setelah itu Bot Father memberikan pesan berisikan informasi sebagai berikut:

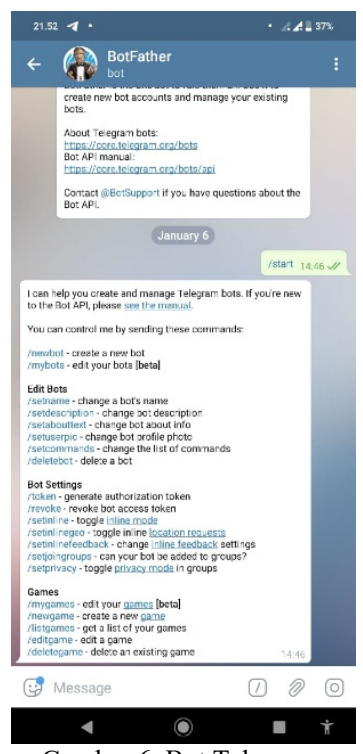

3) ID Telegram

Gambar 6. Bot Telegram

Setiap akun Telegram mempunyai ID yang berbeda-beda yang dapat digunakan untuk memberikan ijin akses mengakses bot yang telah terhubung melalui Modul ESP8266. ID Telegram dapat diketahui dengan mengetikkan "IDBot" pada kolom search. Kemudian menekan tombol "Mulai" dan mengetikkan /getid untuk mengetahui ID akun Telegram seperti berikut: 


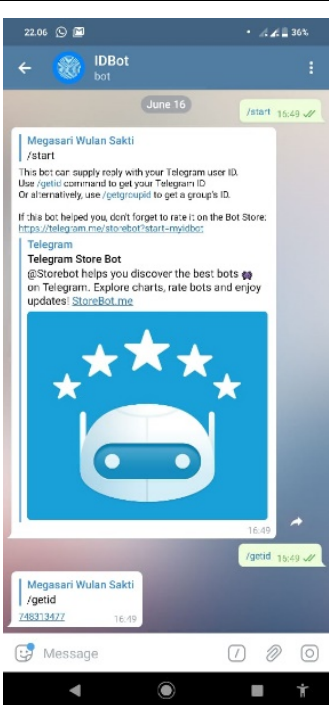

Gambar 7. ID Telegram

4) Program Tampilan Telegram:

Bot Telegram yang telah dibuat tentunya harus dihubungkan ke Arduino melalui Modul ESP8266 yang harus terhubung ke Wi-Fi dengan cara memasukkan ssid dan password Wi-Fi. Kemudian pada program juga harus memasukkan token yang telah diberikan oleh Bot Father dan memasukkan ID Telegram sehingga pengguna dapat mengakses bot tersebut menggunakan akun Telegramnya.

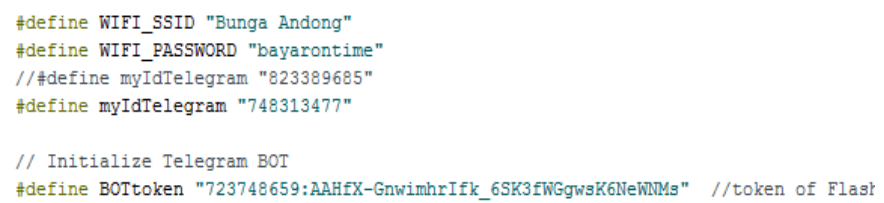

Gambar 8. Input Token

\section{Hasil dan Pembahasan}

\section{A. Implementasi Software}

Implementasi software merupakan hasil dari perencanaan yang telah dipikirkan sebelumnya, meliputi desain untuk memudahkan pengguna mengetahui kondisi kolam ikan lele terkini dan dapat memberikan perintah manual untuk menguras air kolam, mengisi air kolam, menghidupkan heater, dan memberi pakan ikan lele.

Beberapa fitur yang terdapat dalam aplikasi telegram adalah :

- Tombol kuras air berfungsi ketika ph atau kekeruhan tidak normal. User dapat menghidupkan pompa kuras secara manual sesuai keinginannya dan akan mati secara otomatis hingga mencapai jarak $35 \mathrm{~cm}$ dari permukaan air. Setiap tindakan akan diberitahukan ke pengguna bahwa pompa sedang dalam keadaan hidup atau mati.
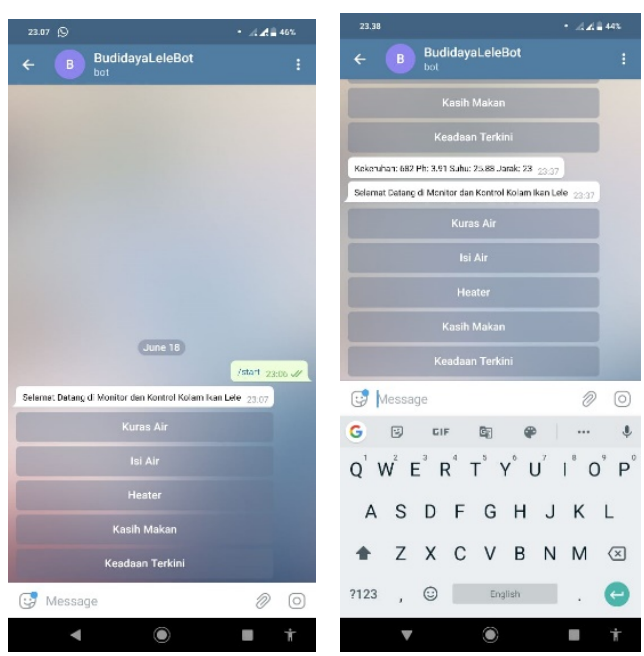

Gambar 9. Implementasi Software

- $\quad$ Prinsip tombol isi air sama dengan tombol kuras air yang nantinya akan memberikan informasi jika aktif maupun tidak dan user dapat menekan tombol jika ingin menghidupkan maupun sesuai keinginannya.

- Prinsip tombol heater berfungsi untuk menghangatkan air ketika suhu air dibawah $25^{\circ} \mathrm{C}$.

- Prinsip tombol kasih makan yaitu tutup pakan terbuka ketika pukul 07.00 dan 19.00 selama 0.5 detik yang kemudian akan tertutup secara otomatis. Pakan akan terjatuh tepat pada bagian motor untuk menyebar pakan sehingga pakan akan tersebar secara merata ke semua sisi. Jika sedang proses memberi makan akan terdapat informasi "proses kasih makan" pada Telegram. User juga dapat menekan tombol pemberian pakan diluar waktu yang telah ditentukan.

- Tombol keadaan terkini bertujuan untuk memberikan informasi keadaan ph, kekeruhan, suhu, dan jarak air secara real time.

\section{B. Implementasi Hardware}

Implementasi hardware sistem monitoring dan telekontrol budidaya ikan lele berfungsi untuk mengetahui keadaan kolam secara real time dan mampu memberikan kontrol secara manual sebagai cadangan. Berikut merupakan tampilan dari sistem tersebut:

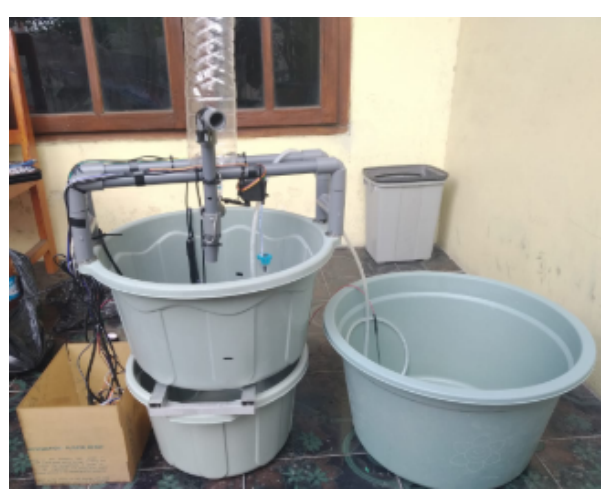

Gambar 10. Implementasi Hardware

Gambar 10 merupakan tampilan secara keseluruhan, bagian bak atas sebagai kolam lele disertai dengan sensor suhu, ph, kekeruhan, pompa, dan motor servo sebagai buka tutup katup pakan, bak bagian bawah sebagai tempat 
pembuangan air yang telah dikuras karena ph atau kekeruhan tidak stabil, bak bagian samping sebagai tempat air bersih untuk mengisi ke dalam bak lele hingga jarak $24 \mathrm{~cm}$ dari permukaan air, dan box komponen diletakkan dibagian bawah pada sisi kiri.

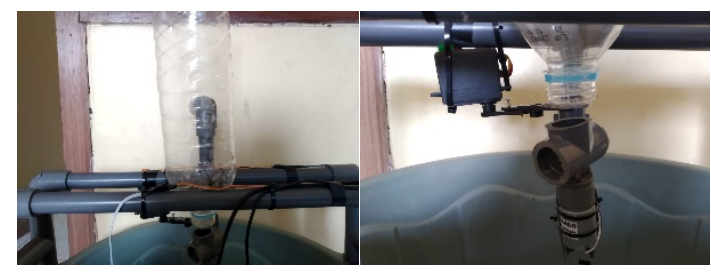

Gambar 11. Implementasi Pakan Ikan

Gambar di atas merupakan tampilan dari sistem pakan ikan. Pakan ikan dimasukkan ke dalam botol aqua dan ditutup oleh motor servo. Ketika waktu makan ikan tiba, maka motor servo membuka tutup pakan sehingga pakan akan terjatuh ke arah bawah untuk disebarkan ke ikan dengan memanfaatkan motor DC selama 0.5 detik.

\section{Pemberian Makan Ikan}

Pemberian pakan ikan berkisar antara $2-5 \%$ perhari atau bahkan lebih. Sedangkan biomas adalah jumlah total ikan perunit area pada waktu tertentu dan diekspresikan dalam $\mathrm{kg} / \mathrm{ha}$ atau $\mathrm{kg} /$ meter persegi [9]. Biasanya dalam pemberian pakan pada ikan yang berukuran besar jumlah pakan yang diberikan setiap hari semakin berkurang dan semakin kecil ukuran ikan jumlah pakan yang diberikan semakin banyak. Hal ini dikarenkan ikan yang berukuran kecil mempunyai masa pertumbuhan yang lebih besar dibandingkan dengan ikan berukuran besar [1].

Pemberian pelet untuk pakan lele 3-5\% dari bobot lele

- Untuk 1 lele anakan (menggunakan pelet berdiameter 2 $\mathrm{mm}$ )

$3 \% \times$ bobot lele $=$ berat pakan

$3 \% \times 5$ gram $=0,15$ gram $(2 \times$ waktu makan $)$

- Untuk 1 lele dewasa (menggunakan pelet berdiameter 4 $\mathrm{mm}$ )

$5 \% \times$ bobot lele $=$ berat pakan

$5 \%$ × 200 gram $=10$ gram $(2 \times$ waktu makan $)$

\section{Pengujian Akurasi Sensor}

Kalibrasi sensor bertujuan untuk menyesuaikan hasil yang diperoleh sensor dan alat ukur memiliki nilai yang sama atau akurat. Setelah dikalibrasi, maka pengujian akurasi sensor dilakukan untuk mengetahui fungsi dari setiap sensor dapat berjalan sesuai dengan perencanaan. Nilai yang diperoleh tentunya memiliki hasil yang berbeda antara alat ukur dan sensor sehingga memunculkan error. Nilai error dapat diketahui dengan menggunakan rumus sebagai berikut:

$$
\% \text { Error }=\frac{(\text { Nilai Sensor }- \text { Nilai Alat Ukur })}{\text { Nilai Alat Ukur }} \times 100 \%
$$

\begin{tabular}{|c|c|c|c|}
\hline No. & $\begin{array}{c}\text { Alat Ukur Suhu Meter } \\
\left({ }^{\circ} \mathrm{C}\right)\end{array}$ & Sensor Suhu $\left({ }^{\circ} \mathrm{C}\right)$ & Error $(\%)$ \\
\hline 1. & 26.3 & 25.12 & 0.04 \\
\hline 2. & 23.5 & 22.5 & 0.04 \\
\hline 3. & 24.5 & 23.06 & 0.06 \\
\hline 4. & 24.7 & 23 & 0.07 \\
\hline 5. & 23.25 & 25.1 & 0.08 \\
\hline 6. & 24.9 & 25.1 & 0.08 \\
\hline 7. & 25.2 & 24.62 & 0.02 \\
\hline \multicolumn{2}{|c|}{ Rata-Rata } \\
\hline
\end{tabular}

Tabel 2. Pengujian Sensor Ph

\begin{tabular}{|c|c|c|c|}
\hline No. & $\begin{array}{c}\text { Alat Ukur PH Meter } \\
\text { (Kalibrator) }\end{array}$ & Sensor PH & Error (\%) \\
\hline 1. & 7 & 7.86 & 0.12 \\
\hline 2. & 6.8 & 6.72 & 0.01 \\
\hline 3. & 6.9 & 7.05 & 0.02 \\
\hline 4. & 7.3 & 7.41 & 0.01 \\
\hline 5. & 6.6 & 6.9 & 0.04 \\
\hline \multicolumn{2}{|c|}{ Rata-Rata } & 0.04 \\
\hline
\end{tabular}

Tabel 3. Pengujian Sensor Turbidity

\begin{tabular}{|c|c|c|c|}
\hline No. & $\begin{array}{c}\text { Alat Ukur Kekeruhan } \\
\text { (NTU) Kalibrator }\end{array}$ & $\begin{array}{c}\text { Sensor Turbidity } \\
\text { (NTU) }\end{array}$ & Error (\%) \\
\hline 1. & 0.78 & 0 & 1 \\
\hline 2. & 0.53 & 0 & 1 \\
\hline 3. & 2.60 & 3 & 0.01 \\
\hline 4. & 72.9 & 89 & 0.22 \\
\hline 5. & 300 & 346 & 0.15 \\
\hline 6. & 418 & 424 & 0.01 \\
\hline \multicolumn{2}{|c|}{ Rata-Rata } \\
\hline
\end{tabular}

Tabel 4. Pengujian Sensor Ultrasonik

\begin{tabular}{|c|c|c|c|}
\hline No & $\begin{array}{c}\text { Jarak menggunakan } \\
\text { Penggaris Kalibrator } \\
(\mathrm{cm})\end{array}$ & $\begin{array}{c}\text { Jarak menggunakan } \\
\text { Sensor Ultrasonik }(\mathrm{cm})\end{array}$ & $\begin{array}{c}\text { Error } \\
(\%)\end{array}$ \\
\hline 1 & 42 & 44 & 0.04 \\
\hline 2 & 34 & 33 & 0.03 \\
\hline 3 & 25 & 26 & 0.03 \\
\hline 4 & 21 & 22 & 0.04 \\
\hline 5 & 19 & 22 & 0.01 \\
\hline \multicolumn{2}{|c|}{ Rata-rata } & 0.03 \\
\hline
\end{tabular}

Dari hasil pengujian pengukuran menggunakan sensor dan alat ukur, didapatkan rata-rata eror yang relatif kecil, yaitu 0.05 pada sensor suhu, 0.04 pada sensor $\mathrm{PH}, 0.4$ pada sensor Turbidity dan 0.03 pada sensor ultrasonik. Hal ini membuktikan bahwa pengukuran menggunakan sensor tidak jauh berbeda dengan pengukuran menggunakan alat ukur, dan hasilnya baik karena masih dibawah toleransi error masing-masing sensor sesuai datasheet.

Pengujian selanjutnya adalah pengujian reaksi output sistem, yaitu pakan, pompa, dan heater dilihat dari data sensor yang masuk. Pengujian dilakukan pada 5 waktu yang berbeda. Dari hasil pengujian beberapa sensor dan sistem, maka dapat diperoleh data sebagai berikut:
Tabel 5. Pengujian Sistem Keseluruhan

\begin{tabular}{|c|c|c|c|c|c|c|}
\hline Waktu & $\begin{array}{c}\text { Suhu } \\
\left({ }^{\circ} \mathrm{C}\right)\end{array}$ & $\mathrm{pH}$ & $\begin{array}{c}\text { Keke } \\
\text { ruhan }\end{array}$ & Pakan & Pompa & Heater \\
\hline 08.33 & 22.5 & 7.78 & 64 & tertutup & mati & hidup \\
\hline
\end{tabular}




\begin{tabular}{|c|c|c|c|c|c|c|}
\hline 11.50 & 30.38 & 7.44 & 128 & tertutup & mati & mati \\
\hline 14.43 & 29.81 & 7.86 & 150 & tertutup & mati & mati \\
\hline 17.06 & 25.19 & 8.24 & 156 & tertutup & mati & mati \\
\hline 19.00 & 21.38 & 8.72 & 158 & terbuka & hidup & hidup \\
\hline
\end{tabular}

Berdasarkan hasil pengujian terlihat bahwa output dari sistem yaitu katup pakan, pompa dan heater telah bekerja sesuai dengan perencanaan. Katup pakan terbuka pada pukul 19.00 sesuai dengan waktu yang telah diatur sebelumnya, pompa pengurasan air akan hidup jika PH kurang dari 6 atau lebih dari 8 atau tingkat kekeruhan lebih dari 400, dan heater akan hidup jika suhu kurang dari 23 derajat.

\section{KeSIMPULAN}

Berdasarkan hasil pengujian dari sistem yang telah dibuat dapat disimpulkan bahwa:

1. Hasil pengujian didapatkan nilai error dari setiap sensor yaitu sebesar sensor suhu $0.05 \%$, sensor ph $0.04 \%$, sensor turbidity $0.4 \%$, dan sensor ultrasonik $0.03 \%$ yang masih dibawah toleransi error masing-masing sensor sesuai datasheet.

2. Guna mempertahankan nilai ph, suhu, dan kekeruhan tetap normal digunakan sistem kontrol ph dan kekeruhan menggunakan sistem kuras dan buang air secara otomatis sesuai level air yang telah ditentukan. Kontrol suhu menggunakan heater agar suhu air tetap terjaga. Sistem ini juga dilengkapi dengan pemberian pakan otomatis yang diberikan setiap 2 kali sehari yang akan terbuka dan tertutup secara otomatis selama 0.5 detik.

\section{REFERENSI}

[1] Aditya, A. S., "Rancang Bangun Pemberi Pakan Ikan Otomatis pada Kolam Ikan Berbasis Arduino", Undergraduate thesis, Program Studi Teknik Komputer, Fakultas Teknologi dan Informatika, Institut Bisnis dan Informatika STIKOM Surabaya, 2017.

[2] Agustina, "Rancang Bangun Sistem Kendali On/Off Lampu Melalui Android Berbasis Mikrokontroler 328" Tesis, Fakultas Komputer, Politeknik Negeri Sriwijaya, 2016.

[3] Albab, M. U. "Prototipe Sistem Monitoring Budidaya Jamur Berbasis Internet Of Things Menggunakan Aplikasi Chatting Telegram", Naskah Publikasi Tugas Akhir Thesis, 2018.

[4] Imaduddin, G. Saprizal, A. "Otomatisasi Monitoring Dan Pengaturan Keasaman Larutan Dan Suhu Air Kolam Ikan Pada Pembenihan Ikan Lele" Jurnal Sistem Informasi, Teknologi Informatika dan Komputer. Universitas Muhammadiyah Jakarta. Vol. 07, No. 02, ISSN 2089-0265, 2017.

[5] Pramana, R. "Perancangan Sistem Kontrol dan Monitoring Kualitas Air dan Suhu Air Pada Kolam Budidaya Ikan" Jurnal Sustainable: Jurnal Hasil Penelitian dan Industri Terapan, Vol. 07, No. 01, hal. 13- 23, ISSN 20875347, Mei 2018

[6] Oktaviadi, R, "Sistem Pemantau Kekeruhan Air Dan Pemberi Makan Otomatis Pada Ikan berbasis Mikrokontroler" Jurnal Ilmiah. Jurusan Teknik Elektro Komputer dan Informatika. Universitas Ahmad Dahlan, Vol 02, No. 01, ISSN 2338-3070, 2016.

[7] Widowati, Hari. "10-keunggulan-telegram-aplikasiperpesanan-pesaing-whatsapp “ di katadata.co.id. 23 Mei 2019

[8] Pramono, yudha, "pengguna-aktif-telegram-tembus-200-juta-" di tekno.kompas.com 24 Maret 2018

[9] SNI, "Ikan lele dumbo (Clarias sp.) - Bagian 3 : Produksi induk" SNI 01-4087-2006 